\title{
Tanulmány
}

\section{Ádám Galac \\ Semantic change of basic perception verbs in English, German, French, Spanish, Italian, and Hungarian ${ }^{1}$}

\begin{abstract}
This study reports on the findings of a contrastive analysis of the changes in the semantic prototypes of basic perception verbs in the history of six European languages: English, German, French, Spanish, Italian, and Hungarian. All verbs found to have functioned as basic perception verbs during a period in one of the languages were included in the research, not only those that are basic perception verbs today. My primary aim was to find historical linguistic data on the cultural role and conceptualization of the five sensory modalities in - the broadly understood - Western society. The patterns that can be observed in the instances of semantic change point to the same domains that Sweetser (1990: 23-48) has found to be associated with vision, audition, gustation, and tactition. Concerning olfaction, its linguistic coding shows three characteristics: olfactory verbs tend to get semantically generalized; the conceptualization of an olfactory event is closer to the "passive frame", as coined by Kövecses (2019); olfactory vocabulary has a strong tendency to acquire negative connotations. Olfaction's culturally assigned role seems to delineate a subordinate, rather unconscious and uncontrollable sensory modality that is often linked with negative emotions.

Keywords: semantic change, perception verbs, etymology, semantic prototype, diachrony
\end{abstract}

\section{Introduction}

Language is one of the most powerful capacities of the human mind, "an instrument for organizing, processing and conveying information" (Geeraerts 1997: 6, cited after Győri 2002: 134). This information is coded in what we call meaning, an inherent quality of linguistic elements, one of the main focuses of modern linguistic research. But "meaning is dynamic and ever changing" (Nerlich \& Clarke 1988: 73), and we do not have to agree with the statement that "one can only explain what meaning is, by explaining how it changes" (ibid.) to see that semantic change is a crucial facet of human language and thus of our capacity to handle information about the world.

In the present analysis, I examine the instances of semantic change in a particular semantic category and in a particular cultural and linguistic environment. This semantic category is that of basic perception verbs: verbs that denote a schematic perceptive event (e.g. see, hear, smell) without adding any specific dimension to its semantic structure (e.g. stare, recognize, stink; see Section 2.1). These verbs are of particular interest because they are one of cognitive

1 Supported by the ÚNKP-19-3 New National Excellence Program of the Hungarian Ministry for Innovation and Technology. 
science's primary windows on the relationship between sensory experience and cognition. From a diachronic point of view, this category encompasses all verbs that functioned as basic perception verbs during a period in one of the studied languages (so stink is relevant for our analysis as its Old English predecessor, stincan used to be a neutral olfactory verb). ${ }^{2}$

The particular cultural environment this research is focused on is Western culture in its broad sense: the culture based on Greco-Roman and Christian origins, characterized by feudalism in the Middle Ages, followed by a process of industrialization from the $18^{\text {th }}$ century. This is reflected by the language sample as well, which is composed of six European languages: English, German, French, Spanish, Italian, and Hungarian (cf. Section 3.1). The rationale behind this cultural perspective lies in the fact that language is in constant interaction with society and culture, and cannot be treated separately from them. Therefore, the generalizations allowed by the outcomes of this analysis only apply to the culturally affected conceptualization of the five sensory modalities, and constitute no universals of human thinking in general.

The principal aim of this study is to find historical linguistic data on the cultural role of the five sensory modalities (vision, audition, olfaction, gustation, and tactition) in the given languages by observing the patterns of change the primary meanings of basic perception verbs have undergone. To my knowledge, the only similar comparative examination of the question is Sweetser (1990: 23-48), who has laid the foundations of the study of the relationship between perception and other cognitive domains in English and many other Indo-European languages (see Section 2.3). But Sweetser's results are based primarily on polysemies and distant and thus uncertain etymologies, and her approach is rather theoretical than methodical. On the other hand, the two main systematic analyses of the subject - Harm (2000) and Fernández Jaén (2012) - are restricted to one language (German and Spanish, respectively). My objective has been to fill in this research gap and to provide a systematic cross-linguistic study of the semantic development of basic perception verbs in the six given European languages.

The structure of this paper is as follows: In Section 2, I discuss the main notions concerning the category of basic perception verbs, define what I mean by semantic change, and review Sweetser's (1990) observations on the domains that are usually linked to the different sensory modalities. Section 3 outlines the methods adopted for my analysis, presents the main sources used for the collection of the data, and indicates the limitations of this research. Section 4 is dedicated to the outcomes of this examination and discusses the sensory modalities one by one, followed by an outline of the semantic development of a highly polysemous multimodal verb in the Romance languages, sentir(e), illustrating the versatility of possible prototype changes a verb (Classical Latin sentio) can undergo. Finally, in Section 5, I recapitulate the most important results of this analysis and point to possible areas of future research.

2 http://www.bosworthtoller.com/finder/3/stincan (23.4.2020). 


\section{Theoretical background}

\subsection{Basic perception verbs}

The present analysis has been carried out against the backdrop of cognitive linguistics, one of the basic tenets of which is that cognition (and thus language) is embodied (cf. Lakoff \& Johnson 1980; Lakoff 1987; Johnson 1987; Langacker 2008; Bergen 2012; Tolcsvai Nagy 2013). Empirical research in psychology, neuroscience and related disciplines has shown that simulation plays a crucial role in thinking, memory, and in the construction of linguistic meaning (Bergen 2012; 2015). We experience the world primarily through our bodies - be it our sense of balance and spatial orientation, our sensation of pain, or what are traditionally called the five senses: vision, audition, olfaction, gustation and tactition -, and the experiences conveyed by these senses function as a basis of how we understand the world. And as perception is intertwined with cognition, so it is closely linked to language as well, which another maxim of cognitive linguistics - reflects our habitual ways of thinking and of conceptualizing the world. Therefore the investigation of the studied languages' means to express basic perceptive events can provide valuable insights into the interrelationship of perception and cognition in the corresponding cultures.

Perceptive events can be grouped into three basic classes, as exemplified in Table $1^{3}$ by the English verbs of auditory perception (cf. Gisborne 2010: 4-8). In the case of subject-oriented conceptualization of perception, the grammatical subject of the verb is the perceiver (i.e. the subject of the perception), whereas the grammatical subject of object-oriented verbs is the percept (i.e. the object of the perception). Subject-oriented verbs are further divided into two subclasses: the experiencer class expresses a pure and inactive type of perception, and the agentive class denotes an active, attentive, deliberate one.

\begin{tabular}{|c|c|c|}
\hline \multirow{2}{*}{ subject-oriented verbs } & experiencer class & hear \\
\cline { 2 - 3 } & agentive class & listen to \\
\hline object-oriented verbs & percept class & sound \\
\hline
\end{tabular}

Table 1. The three classes of perception verbs

The verbs whose primary meaning corresponds to (at least) one of these classes without any additional element or nuance in its event structure are the so-called basic perception verbs. These verbs (e.g. English see, look, hear, smell, etc.) "form a separate class of their own" (Gisborne 2010: 8) and should be treated separately from verbs like recognize, seem, or marvel at, in the case of which pure sensory perception is only a part of or accompanies the action (cf. Harm 2000: 97-99). In another formulation, basic perception verbs are general, and all the others are nuanced in some way ("verbes génériques et verbes nuancés", Piron 2002: 72), having some kind of additional dimension in their prototypical meaning. For example, Gisborne (2010: 9) states that "the meaning of watch includes the notion that the thing which is being watched is expected to change". But, at the same time, he also says that "watch is relevant to my concerns, although not as centrally" (ibid.), which points to the fact that it is sometimes not that evident whether a verb should be considered a basic perception verb or

3 For a comprehensive (synchronic) overview of perception verbs in the six studied languages, see Appendix. 
not. According to Cacciari and Levorato (2003: 4), perception verbs constitute a scale between the so-called "gradient of perception" and the "gradient of cognition", with verbs like It. guardare 'to look at' being closer to the gradient of perception, and verbs like It. identificare 'to identify' closer to the gradient of cognition. ${ }^{4}$ They suggest that verbs of pure perception are those that are located in the first third of the scale towards the gradient of perception (Cacciari \& Levorato 2003: 7).

Not all languages in our study have basic perception verbs for all classes of all sensory modalities. ${ }^{5}$ For instance, the Romance languages can express visual and auditive perception from the perspective of the percept as an agent only through a verb with some additional meaning (e.g. Fr. sembler 'to seem', paraître 'to appear'), through paraphrasing (e.g. Fr. avoir l'air ... 'to have an appearance like ...'), or with the help of a copula, leaving the perceptive event implicit (e.g. Fr. être 'to be'). Similarly, Hungarian lacks basic verbs in the percept class of olfactory, gustatory and tactile perception, and uses either an adjectival compound (1) or possessive constructions (2-3) instead:

(1) $E z \quad a \quad$ tea jó-illat-ú.

this the tea good-smell-ADJ.SFX

(This tea is good-smelling.)

'This tea smells good.'

(2) En-nek a teá-nak jó illat-a van. this-DAT the tea-DAT good smell-POSS be.3SG (This tea has a good smell.)

'This tea smells good.'

(3) En-nek a teá-nak jó az illat-a. this-DAT the tea-DAT good the smell-POSS (The smell of this tea is good.)

'This tea smells good.'

There are also cases where a basic perception verb concurs with such alternative constructions, like that of the percept class of auditive perception in Hungarian, where the verbs hangzik and szól ('to sound, to emit a sound') often give way to the expression valamilyen hangja van ('to have some kind of sound, to have a sound like sg'). This also implies that the frequency of perception verbs varies from one language to another, a factor that should be mentioned even if it is beyond the scope of the present paper. Moreover, Rojo López and Valenzuela (2005) have shown on the example of English and Spanish that the contextual usage of perception verbs belonging to the same class and sensory modality can show significant differences: their quantitative analysis of a bidirectional translation corpus has revealed, for instance, that English percept verbs are often translated as experiencer or agentive verbs in Spanish, and - an even more surprising fact - that the agentive escuchar ('to listen') was translated as hear (experiencer) in $77.8 \%$ of the cases (Rojo López \& Valenzuela 2005: 10-11; 14). Such differences of usage can be observed even in as close cognates as French sentir, Spanish sentir, and Italian sentire (cf. Enghels \& Jansegers 2013).

4 In the empirical part of their research, they asked native speakers to locate a number of perception verbs somewhere between these two gradients, symbolized by a sensory organ and a brain.

5 In the table in the Appendix, different colours are used to distinguish the three classes (experiencer, agentive, and percept) from one another. If a language has no basic perception verb for a class in a sensory modality, the corresponding grid is left white. Possible alternative formulations are included in parentheses. 
I have mentioned these subtle but by far not unimportant factors in order to show the complexity of our research object and to point out the inherent limitations of our analysis. All these aspects cannot be accounted for within the framework of this study, as the synchronic polysemy of the verbs cannot either. Still, as the phenomenon of polysemy is inextricably linked to semantic change, the actual focus of our research, we should now turn to the relation of these two notions.

\subsection{Semantic change}

Most perception verbs are highly polysemous. The English verb see, for instance, has at least nine distinguishable senses, as found by Alm-Arvius (1993: 350-351) in a corpus-based study. But since the principles of categorization are not that self-evident, Gisborne (2010: 118-150) differentiates between twelve, Ibarretxe-Antuñano (1990: 64) between seventeen, and the online Oxford Advanced Learner's Dictionary ${ }^{6}$ between eighteen separate meanings of see. Still, it can be stated with certainty that the relation between these meanings is hierarchical: (at least) one meaning can be considered as the primary one, and the others its extensions. In the semantic network model of cognitive linguistics, this primary meaning, to which the other nodes are related in one way or another, is called the global prototype (Langacker 1990: 266272; Györi 2002: 151-152). There can also be local prototypes that are centers of parts of the network. This situation of polysemy develops into semantic change when a local prototype gets detached from the network and becomes a new global prototype - this process is called prototypicalization (Györi 2002: 152) and constitutes the focus of the present paper. ${ }^{7}$

Semantic change is "far less generalizable than any other type of language change" (Györi 2002: 131). While in phonetics, for instance, there is a finite number of variables susceptible of alternation, "meanings refer to mental content and are thus not characterizable purely through aspects of linguistic structure" (ibid.). This is confirmed by Harm (2000) as well who, after listing some regularities on a low level of generalization (e.g. the meaning of modal verbs shifts from deontic to epistemic modality and not vice versa, words meaning 'little girl' or 'little child' often acquire the meaning 'pupil (in anatomy)' etc.), ${ }^{8}$ concludes that "with the current state of empirical research on phenomena of semantic change, general statements on cross-linguistic regularities are only possible to a limited extent" (Harm 2000: 45). ${ }^{9}$ Fernández Jaén's (2017) investigation takes one more step forward towards the possibilities of generalizing the manifold developments of semantic change, but the tendencies he discusses still pertain to a relatively low level of generalization, i.e. they are restricted to specific semantic domains. Although he is optimistic regarding the future development of this field, stating that "there is no doubt that the path towards a semantics based on scientific laws is very promising"10 (Fernández Jaén 2017: 121), we have to admit that there is still much to explore.

6 https://www.oxfordlearnersdictionaries.com/definition/english/see_1?q=see (7.4.2020).

7 Fernández Jaén $(2017$ : 117) finds that this is in agreement with what chaos theory tells us about processes of growing complexity, according to which a system that has reached a certain state of complexity goes through a phase transition to find a new type of order.

8 Harm (2000: 43-44).

9 Translation by the author. The original text:

„[...] sind beim gegenwärtigen Stand der empirischen Aufarbeitung semantischer Wandelerscheinungen generelle Aussagen zu sprachübergreifenden Regularitäten des semantischen Wandels nur bedingt möglich.“

10 Translation by the author. The original text: 


\subsection{Semantic change of basic perception verbs}

Although the semantic evolution of perceptive vocabulary has long been a topic of interest in historical linguistics (cf. Grimm 1848; Wood 1899; Vendryes 1932), the first systematic overview of the patterns of change was provided by Sweetser (1990). In the second chapter of her book $^{11}$ on semantics and etymology, she examines the semantic development of perception verbs in some Indo-European languages, especially in English. In her qualitative analysis, based on etymologies and polysemies, she argues that the phenomena of semantic change of perception verbs are grounded in what she calls the Mind-as-Body Metaphor, which is "motivated by correlations between our external experience and our internal emotional and cognitive states" (Sweetser 1990: 30). Apart from a few counterexamples, the paths of semantic change "seem to be primarily one-way (concrete $\rightarrow$ abstract, or physical $\rightarrow$ mental)" (Sweetser 1990: 35). After mapping out a number of attested source and target domains of English and some IE perception verbs, she comes to the following generalizations concerning the meaning extensions ${ }^{12}$ that are observable in the different sensory modalities (Sweetser 1990: 32-38):

a. visual perception: objective and intellectual domain, attention, knowledge, control

b. auditive perception: interpersonal communication, obedience

c. tactile perception: general sensory perception, emotions

d. gustatory perception: personal preference

As to olfactory perception, she finds no universal abstract or mental connotations, apart from a rare and peripheral meaning extension of detecting something suspicious by intuition. Neither does Whitt (2010: 25), who only adds to Sweetser's observations that "sometimes verbs signifying gustatory perception can also mean (or are derived from a sense of) 'try' or "choose"." 13

The present analysis of prototype changes in the semantic networks of perception verbs has both confirmed Sweetser's and Whitt's observations and led to novel findings.

"[...] no cabe duda de que el camino hacia una semántica basada en leyes científicas se muestra muy prometedor."

11 Sweetser (1990: 23-48).

12 Sweetser only makes generalizations about the target domains of perception verbs. The sole generalizable source domain based on her data appears to be the names of sensory organs (Sweetser 1990: 32-34; cf. Díaz Vera 2011: 287), but this, too, is only a conjecture that relies on uncertain etymologies.

13 Sweetser only mentions that it is not clear whether the Indo-European root of Latin gustare 'taste (agentive)' originally meant 'taste' or 'try', as its Germanic and Celtic descendents mean 'try' or 'choose' (Sweetser 1990: 36), but she doesn't imply that these two meanings are often related to each other. 


\section{Methods}

\subsection{The object of analysis}

The scope of my analysis encompasses all instances of semantic change where the semantic prototype (or in some cases one of the semantic prototypes) of the source and/or the target meaning of a verb expresses basic sensory perception. An example for the former is English show: this verb used to mean 'see', as did Old English sćéawian and as still do all its reflexes in the continental Germanic languages, but its meaning acquired a causative dimension ${ }^{14}$ in the $14^{\text {th }}$ century to become 'cause to be seen, point out, exhibit' (ODEE: 823). Change in the opposite direction can be exemplified by French entendre 'hear': Latin intendere 'stretch out, reach towards' developed the figurative sense 'be attentive' and then 'understand' (cf. Spanish entender 'understand'), which was the dominant meaning in the $17^{\text {th }}$ century in France, too, but which then got simplified to 'hear', making entendre the basic verb in French to express experiencer auditory perception and pushing ouï 'hear' into obsolescence (LDE: 275). In many cases, though, both the source and the target meaning of a verb express basic sensory perception, and the change lies in the perceptive class it belongs to. Thus, for example, the verb listen, originally meaning 'hear', experienced a prototype shift from the experiencer to the agentive class (ODEE: 531), and the verb look acquired a new prototype in the percept class while retaining the former agentive one (ODEE: 536).

As there is not always a clear boundary between basic or pure perception verbs and those with an additional (supplementary, restrictive, or other) dimension in their meaning (cf. Cacciari \& Levorato 2003, see Section 2.1 above), I had to draw a line between what should be included in the examination (basic and almost basic perception verbs) and what should not. Accordingly, watch is taken into account, but verbs like German wittern (an olfactory verb whose prototypical agent is an animal) are excluded.

A synchronic overview is provided in the Appendix. One part of the analysis consisted in tracing back the history of these verbs, which are currently the basic perception verbs of the studied languages. The other task was to find verbs that functioned as basic perception verbs during a certain period, and then developed some other prototypical meaning. How and based on what sources this was done, is described below (3.2 and 3.3).

The primary aim of this research has been to find historical linguistic data on the conceptualization and the roles of the five sensory modalities in - the broadly understood Western culture. The language sample thus consists of languages that belong to this more or less shared culture, but are genealogically (and in part also typologically) different. English and German belong to the Germanic branch of the Indo-European language family, Italian, Spanish and French to the Romance subgroup of the Italic branch, and Hungarian to the Finno-Ugric branch of the Uralic language family, so it is genealogically not related to the others. Typologically, English can be considered a dominantly isolating language with SVO word order, German an inflectional one with isolating tendencies where both SVO and SOV are typical, French, Spanish and Italian inflectional languages with SVO word order, and Hungarian an agglutinating language with a balance between SVO and SOV (cf. https://wals.info/languoid, 22.4.2020). Furthermore, most of these languages (especially the Romance ones thanks to their ancestor, Latin, but to a certain extent also English and

14 This is a common phenomenon in English (cf. to run - to run a business; to grow - to grow a beard - to grow crops), but the verb show has lost its initial non-causative meaning. 
German) have the advantage that they are well attested historically, so in their cases, we can trace back the history of a comparatively large number of verbs with great certainty.

\subsection{Comparison of the data}

In order to be able to compare the different types of data, I have compiled all instances of semantic change in a table with the following details: language, source meaning, target meaning, source domain, target domain, conceptual transformations (e.g. metaphor, generalization etc.), class shift (experiencer, agentive, percept). There are 59 items (instances of semantic change) in total. Although generally not all aspects are relevant to an item, this uniform description has enabled a systematic analysis of the comparable patterns. The two examples below show two different types of semantic change: in Example 1, source and target domain are of interest and the perceptive classes irrelevant, whereas in Example 2, it is the other way round.

Example 1:

language: Spanish

verb: tañer

meaning 1: 'touch, feel' (agentive)

meaning 2: 'play a musical instrument'

source domain: tactile

target domain: musical

conceptual transformations: metonymy, specification

class shift: -

note: tocar 'touch, feel' has the same musical meaning extension

Example 2:

language: Hungarian

verb: szagol

meaning 1: 'smell' (experiencer and agentive)

meaning 2: 'smell' (agentive)

source domain: olfactory

target domain: olfactory

conceptual transformations: specification

class shift: experiencer and agentive $\rightarrow$ agentive

note: a late development $\left(19-20^{\text {th }}\right.$ century)

\subsection{Sources}

I used several types of sources in order to guarantee the reliability of my data. I will now proceed with their brief description.

Two monographs (on German and Spanish perception verbs) proved to be especially useful sources due to their large set of data and their thorough methodology. Harm (2000) analysed a corpus of German perception verbs spanning from the $8^{\text {th }}$ to the $20^{\text {th }}$ century, using a descriptive language adopted from Job \& Job (1997). This descriptive language is composed of two indicators: the so-called 'process indicator' ${ }^{15}$ refers to the change in the relation between the symbol and the meaning, i.e. to the alternation of the semantic field, whereas the

15 Harm uses four process indicators: focusing, defocusing, change of focus, and focus shift. 
'relation indicator' 16 describes the conceptual relation between the source and the target meaning (Harm 2000: 62-71). Though this descriptive language was designed for the study of semantic change itself on a corpus of perception verbs and is therefore not suitable for our purposes, Harm's data contains basically all relevant information on the semantic development of German perception verbs, and some of his results (Harm 2000: 216-224) are also valuable for our study.

The other essential monograph on the subject is the doctoral thesis of Fernández Jaén (2012), who examines the processes of semantic change and the development of polysemy in Spanish perception verbs on the Corpus Diacrónico del Español (CORDE) and the Corpus de Referencia del Español Actual (CREA) from a cognitive perspective. His work was of paramount importance for this study, especially his investigations on metaphors in connection with the different sensory modalities (Fernández Jaén 2012: 191-233) and his in-depth diachronic analyses of the semantic networks of sentir 'feel' (Fernández Jaén 2012: 393-473), tocar 'touch' (Fernández Jaén 2012: 475-553), and oler 'smell' (Fernández Jaén 2012: 555678), verbs he deems the most polysemous of all (Fernández Jaén 2012: 680).

Besides these comprehensive monographs, a number of other works deal with the historical semantics of perception verbs in the languages under scrutiny here. A brief account of the semantic evolution of French verbs of perception is offered by Piron (2002), and a meticulous doctoral dissertation on the verb entendre 'hear' is Piron (2006). A diachronic study on French sentir 'smell; feel' is conducted by Hertegonne (2014), while Jansegers \& Gries (2017) investigate the history of the same verb in Spanish (sentir 'feel').

In the case of the Romance languages, the examination of the later development of Classical Latin perception verbs could also provide valuable information: here, apart from various dictionaries, especially the Lewis \& Short Latin Dictionary of the Perseus Digital Library, ${ }^{17}$ my main sources were Liver (2003) and Guira (2018).

Apart from the aforementioned works of research literature, I also consulted the most important etymological dictionaries of the studied languages (e.g. ODEE, LDE, TESz., EWUng.). We have to keep in mind, though, that etymologies can only be considered reliable data if the given period of the language in question is sufficiently documented, otherwise they remain conjectures based on "implicit assumptions about the typology of semantic change" (Harm 2000: 124) ${ }^{18}$ In some cases, it is possible to reconstruct the evolution of a polysemy network with the help of Geeraerts' (1997) theory, as Fernández Jaén (2012: 686-687; cf. 126-136) suggests, but etymologies can only be adopted with serious consideration.

Concerning Hungarian, the least attested language in this study, I used the Hungarian Historical Corpus (Magyar történeti szövegtár) ${ }^{19}$ to expand my data. I also consulted the Spanish Diachronic Corpus (Corpus Diacrónico del Español) ${ }^{20}$ of the Spanish Royal Academy to uncover the development of the verb gustar.

\footnotetext{
16 Typical relation indicators are: accompanying action, part of the action, more general action, more specific action, prerequisite.

17 http://www.perseus.tufts.edu/hopper/text?doc=Perseus\%3Atext\%3A1999.04.0059\%3Aentry\%3Dspecto (15.4.2020).

18 „Gute Parallelen sind Etymologien grundsätzlich nicht, da sie ihrerseits auf impliziten Annahmen über eine Typologie des semantischen Wandels beruhen.“

19 http://clara.nytud.hu/mtsz/run.cgi/first_form?corpname=MTSZ;lemma=;lpos= (17.4.2020).

$20 \mathrm{http}: / /$ corpus.rae.es/cordenet.html (17.4.2020).
} 


\subsection{Caveats}

To give a sufficiently reliable and valid account of the data, it is also important to point out the limitations of this analysis. First, as suggested above, the etymology of some perception verbs is uncertain or completely unknown. Second, it is probably impossible to find every verb that for a while functioned as a basic perception verb in at least a variety of one of the studied languages, so we have to put up with the data we have. Third, the same analysis could be carried out in other European languages as well, in order to corroborate or refute our observations. And fourth: the languages in question may have influenced one another during their history, whereupon we have to be careful not to make misleading generalizations. In particular, Latin had an enormous impact on all Western European languages throughout more than a thousand years, but the supremacy of French and in Central Europe also of German should not be underestimated either. For example, the secondary meaning 'aesthetic judgment' of the nouns initially meaning 'taste, gustatory quality' (Latin gustus, French goût, English taste, German Geschmack etc.) is without a doubt a result of cross-linguistic influence. Similarly, Middle High German tasten 'touch (agentive)' is a borrowing from Old French taster 'touch (agentive)' (Harm 2000: 194), just as Hungarian kóstol 'taste (agentive)' is a loanword from German kosten 'taste (agentive)' (TESz. 2: 587), and Hungarian kinéz 'look like (percept)' a calque of German aussehen 'look like (percept)'. In most cases, though, such influence can be excluded, and as we are now primarily interested in what phenomena of semantic change reveal about the role of the different sensory modalities in Western culture, we don't necessarily need to draw a strict distinction between intralinguistic development and cross-linguistic influence.

\section{Outcomes}

This section is dedicated to the presentation of the results of this analysis. After some general observations, I will discuss the five sensory modalities one by one, before concluding with a highly polysemous multimodal verb, sentir(e).

\subsection{General observations}

Transitions between the three classes of perception - apart from the olfactory domain, where they are very frequent (see 4.4) - are rare, and most typical in English. Middle High German sehen (exp. \& ag. > exp. \& ag. \& percept) ${ }^{21}$ and Late (Vulgar) Latin gustare (exp. \& ag. > exp. \& ag. \& percept) ${ }^{22}$ stand as two instances against six (or if we are strict with etymologies, four) English ones: look (ag. > ag. \& percept), listen (exp. > ag.), taste (ag. > exp. \& ag. \& percept), feel (ag. \& exp. > ag. \& exp. \& percept), and maybe see (exp. \& ag. > exp.) and hear (exp. \& ag. > exp.). Further, we have already seen show ('look, see' > 'point out, exhibit'), where a somewhat similar change of perspective took place through causation.

Instances of cross-modal transitions are even fewer. In the case of multimodal sentir( $e$ ), the general meaning of Classical Latin sentio ('perceive') got restricted and profiled as certain

21 In Middle High German, sehen alone could also have a percept meaning, not only aussehen (Harm 2000: $127 ; 155)$.

22 At least in some dialects, as non-Hexagonal (Belgian, Canadian etc.) French goûter 'taste like sg (percept)' and the percept gustatory verbs in all Rhaeto-Romance dialects (Liver 2003: 78) attest. 
sensory modalities became more salient than others in the different Romance languages (see 4.7), but restriction cannot really be regarded as cross-modal change. What surely can, though, is the meaning extension of Hungarian érez, a verb which extended its tactile experiencer prototype to the olfactory and gustatory domain, ${ }^{23}$ thus becoming the only prototypical experiencer verb in three sensory modalities (TESz. 1: 785-786; EWUng. 1: 330). But érez is not the only tactile verb that went through a cross-modal shift: this happened to Late (Vulgar) Latin tastare 'touch, feel (agentive)' as well. This verb, of dubious origins, probably first acquired the meaning 'choose' or 'try', which then developed into 'try the taste of sg' (ODEE: 905; cf. 4.5). Though Spanish tastar is now considered obsolete, it still has both meanings, ${ }^{24}$ and while Italian tastare and French tâter are primarily tactile agentive verbs, tastare can have a gustatory agentive meaning in certain Italian dialects, ${ }^{25}$ and the gustatory dimension of Medieval French taster has yielded the prototypical English gustatory verb of all three classes, taste. The third instance of cross-modal transition is Middle High German smecken/smacken 'taste', a gustatory verb with an experiencer and a percept meaning, that for a while also had an olfactory quality in both classes (Harm 2000: 183184), ${ }^{26}$ which has survived in Upper German dialects. ${ }^{27}$ Apart from these examples, semantic change took place either within one sensory modality, or between a sensory modality and another non-perceptive (source or target) domain.

\subsection{Vision}

Concerning verbs of vision, our examination of semantic prototype changes could confirm Sweetser's (1990: 32-38) paths of semantic change (cf. Section 2.3). Vision is conceptualized in relation with control and power in West Germanic *sexwan ${ }^{28}$ 'follow' $>$ 'follow with the eyes' > 'see, look at' (English see and German sehen, ODEE: 806) and English watch 'be on the alert, guard' ${ }^{29}>$ 'look at, watch' (ODEE: 994), and in relation with attention in Italian guardare 'look at' and French regarder 'look at', both going back to West Germanic *wardon 'be attentive, pay attention to' (DEF: 610-612). This verb meant 'look at, watch' in Old and Middle High German as well (Harm 2000: 127; 134-139), but also 'wait' and 'look after, take care of, ${ }^{30}$ distinct prototypes all in relation with attention (Modern High German has retained the meaning 'wait', but 'take care of' has been specified to 'maintain, service (a machine)'). That vision is associated with the intellectual domain is shown by English regard

23 And also to the domain of general sensations and emotions, see 4.6.

$24 \mathrm{https}: / / \mathrm{dle}$. rae.es/tastar?m=form (16.4.2020).

25 http://www.treccani.it/vocabolario/tastare/ (16.4.2020).

26 It cannot be ascertained which class was first (Harm 2000: 183).

27 https://www.dwds.de/wb/schmecken (16.4.2020). A possible parallel is the case of the Hungarian nouns $i z$ 'taste' and büz 'stench', if the admittedly uncertain etymologies are right (cf. TESz. 1: 405; 2: 250; EWUng. 1: 155, 632): büz, originally neutrally meaning 'smell', could have evolved from iz 'taste', which has attested uses in this sense. Moreover, according to the Oxford English Dictionary, the verb taste can also mean 'smell (experiencer and percept)' in certain English dialects (OED 17: 660; Harm 2000: 185), as Latin sapio 'taste (percept)' had a percept olfactory sense as well (Walde 1910: 677) - even if it is difficult to decide whether these are prototype changes or only meaning extensions.

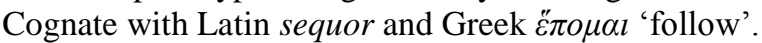

29 Cf. English wake and German wachen 'be awake, keep vigil'.

30 Cf. English wait on sy, attend to sy/sg - attention - French attendre 'wait', and the expression I'll see to it 'I'll take care of it'. 
'look at' > 'consider, think of as' and German betrachten 'contemplate, think of' > 'look at', (Harm 2000: 132-133). In the case of see/sehen, watch, regarder/guardare and betrachten, the associated conceptual domains are not only meaning extensions but sources of the change, which also indicates their close connection with vision (this seems to be a peculiarity of this sensory modality).

\subsection{Audition}

As to auditive perception, the phenomena of semantic change point to a hierarchical interpersonal relation, in which the hearer is on the lower level, following or obeying the speaker's intentions, thoughts, or interests. This is also in compliance with Sweetser's observations. If you truly listen to what somebody says, you understand it (French entendre 'understand' > 'hear') and maybe realize that the person who is speaking is right. Therefore, hearing is often associated with obedience, as German horchen 'listen to' > gehorchen 'obey', Latin oboedio 'listen to' > 'obey', and Hungarian hallgat vkit 'listen to sy' $>$ hallgat vkire 'obey sy' illustrate. But in order to be able to hear something (not necessarily someone's words), at times you have to stop what you are doing and be quiet (also conforming to an external factor): this has been lexicalized in Middle High German ( $\hat{f} f)$ hoeren ${ }^{32}$ 'listen to' > 'prick up one's ears' > 'stop doing sg' and Hungarian hallgat 'listen to' > 'be quiet'.

\subsection{Olfaction}

Olfaction is the domain where our analysis has yielded the most interesting and original findings. These are the following: 1 . Transitions between the perceptive classes are unusually frequent, the meaning of olfactory verbs tends to get generalized. 2. The perceiver of an olfactory object is conceptualized as a passive agent (in the sense of Kövecses 2019). 3. Olfactory vocabulary has a strong tendency to acquire negative connotations.

\subsubsection{Transitions between the classes}

Transitions between the three classes (experiencer, agentive, and percept) are significantly more frequent than in other sensory modalities (eight instances in olfaction as opposed to eight in every other modality together). This is primarily due the generalization of an olfactory verb's meaning to all three classes, which is what happened in the case of English smell (no data on which class it belonged to originally), German riechen (percept $>$ all three, Harm 2000: 176-178), extinct Middle High German draehen (percept > all three, Harm 2000: 180), Spanish oler (percept > all three, Fernández Jaén 2012: 565), French sentir and Italian sentire (experiencer $>$ all three). This has resulted that today, four out of the six studied languages (English, German, French and Spanish) use only one basic olfactory verb for all

31 This change from an abstract into a concrete meaning is especially interesting as the only parallel found in this study is French entendre 'understand' > 'hear' (LDE: 275, see Section 3.1). Counterexamples (cf. Sweetser 1990: 23-48) are much more numerous: e.g. English regard, Latin considerare, contemplari/contemplare, Greek $\sigma \kappa \varepsilon \dot{\pi} \tau \sigma \rho \alpha l$ 'look at' > 'think about' (Harm 2000: 133).

32 In Middle High German, the verbal prefix $\hat{u} f$ - didn't play any differentiating role between the meanings, so both hoeren and iffhoeren could mean 'listen to', 'prick one's ears' and 'stop doing sg' (Harm 2000: 171173). In Modern German, this is not the case anymore: hören means 'hear (exp.); listen to (ag.)', aufhören 'stop'. 


\section{Ádám Galac: Semantic change of basic perception verbs \\ Argumentum 16 (2020), 125-146 \\ Debreceni Egyetemi Kiadó \\ DOI: 10.34103/ARGUMENTUM/2020/9}

three classes (smell, riechen, sentir, and oler, respectively). ${ }^{33}$ Although its experiencer usage has disappeared and its percept meaning has undergone pejoration since then, Old High German stincan also used to express both experiencer and percept olfactory perception (Harm 2000: 174).

This generalization of perception verbs is not typical for the other sensory modalities, as only English taste and feel have extended their meaning this way, and, as we have seen in 4.1, this is not an unusual phenomenon in English (cf. also the change of perspective in show 'make visible' vs. show through 'be visible behind or under something else'). Our data contains only one counterexample, that of Hungarian szagol, ${ }^{34}$ which, based on its occurrences in the Hungarian Historical Corpus, used to have an agentive and an experiencer prototype as well, though the latter has since become a yet possible, but rare and nonprototypical meaning.

As an explanation to this phenomenon that languages tend to put up with one verb to express all kinds of olfactory action, it can be argued that the low cultural significance and the low level of consciousness of olfactory experiences may play a role in it.

\subsubsection{A passive sensory modality}

Our data seems to support the proposition by Kövecses (2019: 343) that it is probably the passive frame that best represents the conceptual prototype of smell. "In this frame of smell, the organism with the faculty of smell functions in the role of patient or experiencer; the experience of smell occurs to the organism" (Kövecses 2019: 332). One of the most important characteristics of olfactory perception is the lack of control (Kövecses 2019: 342; Fernández Jaén 2012: 683), and this can be seen in its language-based folk theory as well. First, out of the four instances found by Harm where metonymy does not take place in the direction part > whole but vice versa, three concern verbs in the olfactory domain: riechen 'emit smoke or vapour' > 'emit a smell', draehen 'swirl (as of smoke or vapour)' > 'emit a smell', and smecken/smacken 'have or experience a taste' > 'emit or experience a smell' (Harm 2000: 222). These changes delineate a concept of smell according to which it is only part of an action, merely accompanying something we overtly talk about or consciously experience. Second, Latin and the Romance languages lack basic percept verbs in the visual, auditory, and tactile range, which correlates with Harm's (2000: 218) observation that percept verbs of the visual, auditory, and tactile modalities were formed in a comparatively late period of the German language, i.e. in Middle High German (visual and auditory) and in Modern High German (tactile). If we consider that French $^{35}$ also lacks basic percept verbs for the gustatory

33 As in Italian the verb sentire is reserved primarily for experiencer auditive perception (cf. 4.7), speakers have to be more explicit when talking about olfaction, and thus the expression sentire odore di qc is more typical for the experiencer class, avere odore di $q c$ for the percept class, and the agentive meanings are expressed by the concurring verbs sentire, odorare, annusare and fiutare.

34 An example from 1841: „Az ember nem csak magán kivül és maga körül, a' térben 's időben fekvő, vagy inkább mozgó külvilágban, érzelhet, a'midőn lát, hall, szagol, ízelít és tapint; hanem, mint fillozofáló, önmagába [...]” (Péterfi Károly: Alapfilozófia, p.7; Magyar történeti szövegtár:

http://clara.nytud.hu/mtsz/run.cgi/first?corpname=MTSZ\&reload=\&queryselector=iqueryrow\&iquery=szago

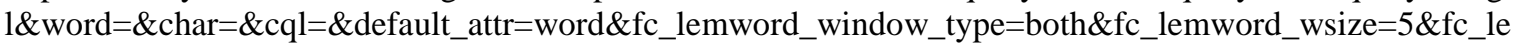

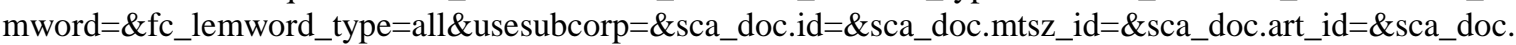
author=\&sca_doc.title=\&sca_doc.pubTitle $=\& s c a \_d o c .1$ form_field $=\& s c a \_d o c$. wdate $=\& s c a \_d o c$. wdateorder $=$ \&sca_oldal.oldalszam=; 16.4.2020).

35 Apart from the non-Hexagonal French usage of goûter as a percept verb (see footnote 22). 
domain, it turns out that olfaction is the only modality where every studied Western European language $^{36}$ has a percept verb, which also corroborates the assumption that smell is conceptualized by the passive frame more typically than the other four senses. Moreover, half of the generalizations described in 4.4.1 originated from percept verbs, making olfaction the only sensory modality where a percept verb can generate a class shift (at least according to our data). The predominance of the percept class is a further indication that olfaction is linguistically coded as a rather passive, non-voluntary perceptual modality.

\subsubsection{Pejoration of meaning}

The vocabulary of olfactory perception is prone to taking negative connotations, and sometimes this leads to the pejoration of the global prototype as well. The most prominent example is Old English and Old High German stincan, which used to have a neutral percept meaning, but which gave English stink and stench and German stinken 'stink' (ODEE: 867, 870; Harm 2000: 185-186). Though no prototype change has taken place, English smell also has a negative connotation when used alone (if one says that something smells, it actually means it smells bad) and requires a positive complement to alter this. The same is true of Spanish oler (Fernández Jaén 2012: 572) and French sentir, ${ }^{37}$ even if these languages have prototypical negative percept olfactory verbs as well (Spanish apestar, French puer). In Hungarian, the percept verb derived from the noun szag 'smell', szaglik, can only refer to the emission of unpleasant smells (though not as strongly as büzlik 'reek'), and the construction that is used for the percept class, szaga van 'have a smell, emit a smell', has a similar negative overtone, just as the noun szag 'smell' in itself. And, as mentioned above, the highly negative meaning of büz 'stench' has presumably evolved from a neutral 'smell', too. Since all instances of pejoration in our data are found within the olfactory domain, it seems especially characteristic of this modality.

That the vocabulary of olfaction has a tendency towards pejoration in Western culture is probably rooted in the fact that one of the main functions of this sense $\mathrm{e}^{38}$ is to detect dangerous or unhealthy substances. Usually, we make no big deal of how something smells, but if something smells bad, it is a much stronger experience ${ }^{39}$ than if something looks or sounds unpleasant - not only aesthetically, but also functionally, since unpleasant smells often denote danger. This strong negative quality is reflected by language as well.

36 Hungarian is different in this respect, as it only has basic (and semantically neutral, see 4.4.3) percept verbs for vision and audition, expressing the object-oriented dimension of the other sensory modalities with nominal constructions.

37 One of the three meanings of intransitive (percept) sentir listed by the Larousse online dictionary is "dégager une mauvaise odeur" ('to emit a bad smell'), and the corresponding example is the only one where the verb stands alone, without a complement.

https://www.larousse.fr/dictionnaires/francais/sentir/72148?q=sentir\#71345 (16.4.2020).

38 We primarily use our vision and audition for orientation and other practical purposes, and are not used to direct contact with natural odours, which provoke a defensive reaction in most of us (cf. Fernández Jaén 2012: 685).

39 Salesse (2015: 27) points out that the orbitofrontal cortex, where the olfactory stimuli are processed, is activated more by repulsive smells than by pleasant ones. 


\subsection{Gustation}

In the current date set, I have found two main tendencies regarding the prototype changes of gustatory perception verbs, and could thus confirm the assumptions of both Sweetser (1990: 38) and Whitt (2010: 25).

First, contrary to olfactory vocabulary, words belonging to the gustatory domain often acquire positive connotations (cf. Sweetser 1990: 38). There are three such instances in our data: German schmecken, Hungarian izlik, and Romance gustar(e). The development of schmecken and izlik is similar: both are percept gustatory verbs that have gone through amelioration of meaning so that now they prototypically (that is, without a complement that alters this) mean 'taste good', and not merely 'taste somehow, have a taste'. Gustar(e) is somewhat different. Latin gusto used to be an agentive and an experiencer verb, whose meaning gradually shifted towards that of enjoying and liking. In the $17^{\text {th }}$ century, this was its prototypical sense in Spanish, but its grammatical subject was still the person who enjoyed, liked or wanted something. ${ }^{40}$ Then the figures in its semantic structure got reversed, so today A gusta a B means 'B likes A' (the same construction as German gefallen, Hungarian tetszik, Latin placeo, French plaire, and Italian piacere). The prototypical meaning is purely psychological, Spanish gustar is not a perception verb anymore (Fernández Jaén 2005: 403). In Italian, this shift also took place, but gustare has retained its other two meanings as well, so today this verb can have the following senses: 'taste (agentive or experiencer)'; 'enjoy, savour'; 'please, be pleasing, be liked'. ${ }^{41}$ It seems to me that the development of this verb in the various Romance languages and dialects would be worth a more thorough investigation.

The second pattern that can be observed in our data is that agentive gustatory verbs are typically derived from a verb meaning 'try' (cf. Whitt 2010: 25). Three instances are certain: German probieren, Spanish probar, and Italian assaggiare. Further, as described in 4.1, tastare 'touch (agentive)' probably developed its gustatory sense 'taste (agentive)' also through 'choose, try' (ODEE: 905). And although the primary sense of the Indo-European root * geus-, which gave Latin gustare and German kosten, remains indefinite, numerous descendents (cf. Sweetser 1990: 36; Walde 1910: 357) point to a relation between tasting (Greek, Latin) and trying (German, Celtic) - in conjunction with a positive hedonistic connotation in the sense of 'enjoy' (Indo-Iranian), as discussed above.

Even though it rather constitutes an exception than a general pattern, we have to mention the Latin percept gustatory verb sapio, that - besides an olfactory meaning extension, as mentioned above - had the intellectual sense 'know, understand, be wise'. ${ }^{42}$ It is uncertain how these two meanings became associated with one another ${ }^{43}$ (the Larousse French

40 An example from between 1654-1658: "Para los 20 de Enero le tienen prevenido á la Reina en la Zarzuela una gran comedia y otros muchos divertimientos, donde gusta de ir todos los años."

(Jerónimo de Barrionuevo, Avisos III, p. 119; Corpus Diacrónico del Español:

http://corpus.rae.es/cgi-

bin/crpsrvEx.dll?visualizar?tipo1=5\&tipo2=0\&iniItem=0\&ordenar1=0\&ordenar2=0\&FID=170420 $011 \backslash \mathrm{C} 00$

$0017042020115903638.1020 .1016 \& \operatorname{desc}=\{B\}+\{I\}+$ gusta $\{\mid I\},+$ en $+\{I\} 1200-$

$1700\{\mid \mathrm{I}\},+$ en+todos+los+medios, + en $+\{\mathrm{I}\}$ CORDE $+\{\mid \mathrm{I}\}+\{\mid \mathrm{B}\}\{\mathrm{BR}\} \&$ marcas $=0,17.4 .2020)$.

Compare also Portuguese gostar 'enjoy, like' that is still used this way:

https://dictionary.cambridge.org/dictionary/portuguese-english/gostar (17.4.2020).

41 http://www.treccani.it/vocabolario/gustare/ (17.4.2020).

42 Walde 1910: 677;

http://www.perseus.tufts.edu/hopper/text?doc=Perseus:text:1999.04.0059:entry=sapio (17.4.2020).

43 Compare the extraordinary meaning extensions of Egyptian $d p$, a prototypical experiencer gustatory verb (Steinbach 2015). 
Etymological Dictionary suggests the development 'have a taste' > 'penetrate sg' > 'understand sg', LDE: 747), but the verb gradually eliminated scio and became the primary Romance verb expressing knowledge: French savoir, Spanish saber, Italian sapere. ${ }^{44}$

\subsection{Tactition}

Sweetser (1990: 37-38) describes that tactition often functions as a source domain for general sensory experience and for emotions. This is corroborated by the prototype extensions of English feel, German fühlen, and Hungarian érez (the latter, as noted in 4.1, also becoming the prototypical experiencer verb for olfaction and gustation, besides expressing general external or internal sensations). And although only these three verbs have experienced a change in their global prototype, several other tactile verbs can be used in this sense, too: compare English touch, French toucher, German berühren, Hungarian (meg)érint.

Few other patterns can be observed. Two agentive verbs, Vulgar Latin toccare (Italian toccare, Spanish tocar, French toucher, English touch) and Hungarian tapint, tapogat may share the same source domain, as probably both are of onomatopoeic origin (DEF: 641-643; LDE: 836; TESz. 3: 845-846; EWUng. 1: 1481; 1529), but it is difficult to draw a conclusion from this fact. The sole remaining parallelism - the musical/auditory meaning extension of Medieval Spanish agentive tañer ( $<$ Latin tangere), which finally led to the modification of the verb's prototypical meaning, ${ }^{45}$ and the emergence of the same auditory prototype in tocar $^{46}$ - is intralinguistic, and the development of tocar was probably influenced by the semantic qualities of tañer (Fernández Jaén 2012: 551).

\subsection{The Romance verb sentir(e)}

French sentir, Spanish sentir and Italian sentire are all highly polysemous verbs, but their semantic networks are not exactly equivalent. Numerous in-depth intralinguistic and contrastive studies have been carried out on their exact contextual use in the different languages (Franckel 2004; Theissen 2011; Enghels \& Jansegers 2013; Hertegonne 2014; Fernández Jaén 2016; Jansegers \& Gries 2017), but a comprehensive overview of the subject goes beyond the scope of this paper. In this section, I will only provide an outline of the changes in the semantic prototypes of Latin sentio in the three studied Romance languages.

Classical Latin sentio was a general experiencer verb that didn't belong to a sensory modality in particular. It could refer to any external or internal physical sensation (e.g. pain) and to any of the five modalities (in this sense it was probably close to English perceive). Besides, it could also be used as a cognitive verb with the meaning 'think, deem, judge', but it could not refer to emotions. ${ }^{47}$

44 As can be seen in the Appendix, Spanish saber and Italien sapere have retained their gustatory sense, too, while French savoir only means 'know' (though la saveur 'taste, savour').

45 In today's Spanish, tañer is prototypically used in the senses 'play a musical instrument' or 'ring a bell'.

46 I would argue that the auditory meaning in tocar is at least a local prototype in its semantic network, and definitely not just an extension of its primary tactile meaning, since it can refer to a much wider range of musical or auditory actions: e.g. tocar la guitarra 'play the guitar', tocar una pieza de baile 'play a dance piece', tocar la bocina 'honk the horn'.

47 http://www.perseus.tufts.edu/hopper/text?doc=Perseus:text:1999.04.0059:entry=sentio (17.4.2020). See also Jansegers \& Gries (2017: 4). 
The three Romance languages have all maintained the primary prototype of the verb that refers to general physical sensation (heat, temperature, pain etc.). They have also preserved its capacity to refer to the so-called "lower senses": olfaction, gustation and tactition. But all three have lost its cognitive sense, and all three have introduced another dimension, that of emotions. (I am referring to them here as all three for the sake of simplicity, but they may have not been separate languages at the time - this needs further investigation.)

What they did do individually, though, was making one or the other meaning of the verb more salient, changing it into a new prototype. Italian made sentire the prototypical experiencer verb of auditory perception (replacing udire < audire), whereby French sentir lost its capacity to refer to hearing, and became the prototypical olfactory verb. In the case of Spanish sentir, it is not that evident which meaning should be considered prototypical: according to Fernández Jaén (2005: 399), it is the tactile one, but probably because he treats tactition in the same category as all other external physical sensations, while Jansegers and Gries' (2017: 4) quantitative analysis has showed that the verb is most frequently used to refer to emotional perception. This is due to the fact that sentir acquired a very salient negative emotional meaning in Spanish: 'be sorry for sg' (so that lo siento - literally 'I feel it' - means 'I'm sorry').

Table 2 shows the experiencer domains this verb can be used in in the different languages: the possible meanings are marked with light grey, the more dominant (prototypical) ones with dark grey.

\begin{tabular}{|l|l|l|l|l|l|l|l|l|}
\hline & general & vision & audition & olfaction & taste & touch & cognition & emotion \\
\hline L. sentio & & & & & & & & \\
\hline Fr. sentir & & & & & & & & \\
\hline Sp. sentir & & & & & & & & \\
\hline It. sentire & & & & & & & & \\
\hline
\end{tabular}

Table 2. The experiencer meanings of sentir(e) in Classical Latin, French, Spanish and Italian

Spanish sentir has remained an experiencer verb in spite of all its rich polysemy, but French sentir and Italian sentire have extended their olfactory meaning to the agentive and percept classes as well (just like Spanish oler, cf. 4.4.1). They became the primary olfactory verbs in these languages (even if the dominant meaning of Italian sentire expresses experiencer auditive perception), eliminating the descendents of Latin oleo.

\section{Conclusion}

In this study, I examined the instances of semantic prototype changes of basic perception verbs in English, German, French, Spanish, Italian, and Hungarian. My main question was how historical linguistic data reflects the cultural role and conceptualization of the five sensory modalities (vision, audition, olfaction, gustation, and tactition) in Western society. Based on the data investigated, the following claims may be formulated: 
First, the analysis has confirmed Sweetser's (1990) observations (see Section 2.3) on the relationship between the different sensory modalities and other conceptual domains, namely that vision is generally associated with control, power, attention, and the intellectual domain, audition with hierarchical interpersonal relations, tactition with general sensations and emotion, and gustation with personal preferences. I could also provide several examples for the change 'try' $>$ 'taste (agentive)' (cf. Whitt 2010: 25). This means that the connection of these domains with the given sensory modalities is not only visible in the polysemy of perceptual vocabulary, but it is also reflected in the way semantic prototypes of perception verbs evolve. Concerning vision, the associated conceptual domains are more than just possible meaning extensions, since they are often source domains of the change (e.g. English watch for control and attention, and German betrachten for the intellectual domain, see Section 4.2).

Even more interesting are the findings regarding olfactory perception (see Section 4.4), a modality about which few general observations have been made yet from a linguistic point of view. First, I have found that transitions between the three perceptive classes (experiencer, agentive, and percept) are significantly more frequent in this sensory modality than in any other. Most of these transitions lead to the generalization of a meaning that belongs to one of the classes to all three - which may be in connection with the low cultural significance and the low level of consciousness of olfactory experiences in Western society. Second, the dominance of the percept class over the other two and some whole > part metonymies uncovered by Harm (2000: 222) seem to corroborate Kövecses's (2019: 343) assumption that the conceptual prototype of smell is probably best represented by the passive frame. And third, contrary to gustatory perception, olfactory vocabulary tends to acquire negative connotations, which leads to the pejoration of the prototypical meaning of percept olfactory verbs.

Naturally, as shown earlier (cf. Section 3.4), this research also has its limitations. Not every verb relevant for this study has a well-documented history, which makes it impossible to reconstruct its exact semantic development. It is probably also impossible to find every verb that was at some point used as a basic perception verb at least in a variety of one of the studied languages, which excludes the possibility of a statistical examination. Still, this qualitative, exploratory, comparative analysis has yielded valuable new information on how perceptive events are linguistically conceptualized in Western society, and its limitations delineate possible areas of future research. Among others, one could examine the whole polysemy structure or the prefixed (e.g. Hungarian lenéz vkit 'look down upon sy') and phrasal (e.g. English look after sy) variations of these verbs, though both would immensely increase the complexity of the problem. As mentioned in Section 2.1, the frequency of the different perception verbs varies from one language to another, and its study may also provide useful information on the significance of the concepts represented by each verb in the various languages. And, of course, other European languages could be included in the examination, as well as languages belonging to completely different cultures. 
Ádám Galac: Semantic change of basic perception verbs

Argumentum 16 (2020), 125-146

Debreceni Egyetemi Kiadó

DOI: 10.34103/ARGUMENTUM/2020/9

\section{References}

Alm-Arvius, C. (1993): The English Verb See: A Study in Multiple Meaning. Göteborg: Acta Universitatis Gothoburgensis.

Bergen, B. K. (2012): Louder Than Words. The New Science of How the Mind Makes Meaning. New York: Basic Books.

Bergen, B. K. (2015): Embodiment, simulation, and meaning. In: Riemer, N. (ed.): The Routledge Handbook of Semantics. London \& New York: Routledge, 142-157.

Cacciari, C. \& Levorato, M. C. (2003): "Res accendent lumina rebus". La descrizione dell'esperienza sensoriale, ovvero dei rapporti fra percezione e linguaggio. In: Savardi, U. \& Mazzocco, A. (eds.): Figura e sfondo. Temi e variazioni per Paolo Bozzi. Padova: CLEUP, 179-200.

Díaz Vera, J. E. (2011): Derivation in a word-based morphology: on the origin of Old English verbs of perception, cognition and emotion. Linguistica 51.1, 285-290. https://doi.org/10.4312/linguistica.51.1.285-290

Enghels, R. \& Jansegers, M. (2013): On the crosslinguistic equivalence of sentir(e) in Romance languages: A contrastive study in semantics. Linguistics 51.5, 957-991. https://doi.org/10.1515/ling-2013-0034

EWUng. = Benkö, L. et al. (Hrsg.) (1993-1995): Etymologisches Wörterbuch des Ungarischen 1-2. Budapest: Akadémiai Kiadó.

Fernández Jaén, J. (2005): Verbos de percepción sensorial en español: una clasificación cognitiva. Interlingüística 16.1, 391-405.

Fernández Jaén, J. (2012): Semántica cognitiva diacrónica de los verbos de percepción física del español. Tesis doctoral. Alicante: Universidad de Alicante.

Fernández Jaén, J. (2016): Usos modales y epistémicos del verbo sentir. Revista de Investigación Lingüistica 19, 199-226.

Fernández Jaén, J. (2017): Las leyes del cambio semántico: una reflexión epistemológica. Quaderni di semantica: rivista internazionale di semantica teorica e applicata 3-4.1, 87124.

Franckel, J.-J. (2004): Sens / sentir. Linx 50, 103-134. https://doi.org/10.4000/linx.140

Geeraerts, D. (1997): Diachronic Prototype Semantics. A Contribution to Historical Lexicology. Oxford: Clarendon Press.

Gisborne, N. (2010): The Event Structure of Perception Verbs. Oxford: Oxford University Press. https://doi.org/10.1093/acprof:oso/9780199577798.001.0001

Giura, F. (2018): Activity ed Experience nei verbi latini di percezione uditiva. Mutamento linguistico e biodiversità. Atti del XLI Convegno della Società Italiana di Glottologia, 1-3 dicembre 2016. Perugia: Università per Stranieri, 259-264.

Grimm, J. (1848): Die fünf sinne. Zeitschrift für deutsches Altertum 6, 1-15.

Győri, G. (2002): Semantic change and cognition. Cognitive Linguistics 13.2, 123-166. https://doi.org/10.1515/cogl.2002.012

Harm, V. (2000): Regularitäten des semantischen Wandels bei Wahrnehmungsverben des Deutschen. Stuttgart: Franz Steiner Verlag.

Hertegonne, E. (2014): Étude diachronique des propriétés sémantico-syntaxique du verbe de perception sentire/sentir du latin jusqu'au français contemporain. Ghent: Universiteit Gent.

Ibarretxe-Antuñano, I. (1990): Polysemy and Metaphor in Perception Verbs: A CrossLinguistic Study. Doctoral Thesis. Edinburgh: University of Edinburgh. 
Jansegers, M. \& Gries, S. Th. (2017): Towards a dynamic behavioral profile: A diachronic study of polysemous sentir in Spanish. Corpus Linguistics and Linguistic Theory, to appear.

Job, M. \& Job, U. (1997): Überlegungen zum semantischen Wandel. In: Gather, A. \& Werner, H. (Hrsg.): Semiotische Prozesse und natürliche Sprache. Festschrift für Udo L. Figge zum 60. Geburtstag. Stuttgart, 255-272.

Johnson, M. (1987): The Body in the Mind: The Bodily Basis of Meaning, Imagination and Reason. Chicago \& London: The University of Chicago Press. https://doi.org/10.7208/chicago/9780226177847.001.0001

Kövecses, Z. (2019): Perception and Metaphor. The Case of Smell. In: J. Speed, L., O’Meara, C., San Roque, L. \& Majid, A. (eds.): Perception Metaphors (Converging Evidence in Language and Communication Research 19). Amsterdam \& Philadelphia: John Benjamins, 327-346. https://doi.org/10.1075/celcr.19.16kov

Lakoff, G. (1987): Women, Fire and Dangerous Things. Chicago \& London: The University of Chicago Press. https://doi.org/10.7208/chicago/9780226471013.001.0001

Lakoff, G. \& Johnson, M. (1980): Metaphors We Live By. Chicago \& London: The University of Chicago Press.

Langacker, R. W. (2008): Cognitive Grammar. A Basic Introduction. Oxford: Oxford University Press. https://doi.org/10.1093/acprof:oso/9780195331967.001.0001

Langacker, R. W. (1990): Concept, Image, and Symbol: The Cognitive Basis of Grammar. Berlin \& New York: Mouton de Gruyter.

LDE = Dubois, J. \& Mitterand, H. \& Dauzat, A. (2007): Larousse Dictionnaire étymologique. Paris: Éditions Larousse.

Liver, R. (2003): Die Verben der sinnlichen Wahrnehmung im Bündnerromanischen. Vox Romanica 62.1, 67-85.

Nerlich, B. \& Clarke, D. D. (1988): A Dynamic Model of Semantic Change. Journal of Literary Semantics 17, 73-90. https://doi.org/10.1515/jlse.1988.17.2.73

ODEE = Onions, C. T. (Ed.) (1967): The Oxford Dictionary of English Etymology. Oxford: Clarendon Press.

OED = Simpson, J. A. \& Weiner E. S. C. (eds.) (1989): The Oxford English Dictionary. Second Edition. Vol 1-20. Oxford: Oxford University Press.

Piron, S. (2002): Évolution sémantique des verbes de perception en français : une approche lexicale. Actes du XVI colloque des Journées de linguistique, 15-16 mars, AEDILL. Québec: Université Laval, 71-82.

Piron, S. (2006): Analyse et représentation des connaissances en sémantique verbale. $L$ 'interface syntaxe-sémantique du verbe entendre. Thèse de doctorat. Montréal: Université du Québec à Montréal.

DEF = Picoche, J. (1979): Dictionnaire étymologique du français. Paris: Le Robert.

Rojo López, A. M. \& Valenzuela, J. (2005): Verbs of sensory perception: An English-Spanish comparison. Languages in Contrast 5.2, 219-243. https://doi.org/10.1075/lic.5.2.03lop

Salesse, R. (2015): Faut-il sentir bon pour séduire? 120 clés pour comprendre les odeurs. Versailles: Éditions Quae.

Steinbach, E. (2015): „Ich habe seinen Anblick geschmeckt...“ Verben der Wahrnehmung zwischen Perzeption und Kognition. In: Behlmer, H. \& Junge, F. (Hrsg.): Göttinger Orientforschungen IV. Reihe Ägypten 59. Wiesbaden: Harrassowitz Verlag, 209-225. https://doi.org/10.2307/j.ctvc2rkg8.15 
Sweetser, E. (1990): From Etymology to Pragmatics. Metaphorical and Cultural Aspects of Semantic Structure. Cambridge: Cambridge University Press. https://doi.org/10.1017/CBO9780511620904

TESz = Benkő, L. et al. (eds.) (1967-1976): A magyar nyelv történeti-etimológiai szótára 1-3. Budapest: Akadémiai Kiadó.

Theissen, A. (2011): Sentir : les constructions prédicatives de l'olfaction. Langages 181, 109125. https://doi.org/10.3917/lang.181.0109

Tolcsvai Nagy, G. (2013): Bevezetés a kognitív nyelvészetbe. Budapest: Osiris.

Vendryes, J. (1932): Sur les verbes qui expriment l'idée de 'voir'. Académie des inscriptions et belles-lettres, comptes rendus de l'année 1932, 192-206. https://doi.org/10.3406/crai.1932.76206

Walde, A. (1910): Lateinisches Etymologisches Wörterbuch. Zweite umgearbeitete Auflage. Heidelberg: Carl Winter's Universitätsbuchhandlung.

Whitt, R. J. (2010): Evidentiality and Perception Verbs in English and German. Bern: Peter Lang. https://doi.org/10.3726/978-3-0353-0306-3

Wood, F. A. (1899): The Semasiology of Words for 'Smell' and 'See'. PMLA 14.3, 299-346. https://doi.org/10.2307/456640

\author{
Ádám Galac \\ Eötvös Loránd University Budapest \\ Intercultural Linguistics Doctoral Programme \\ H-1088 Budapest \\ adam.galac@gmail.com
}


Ádám Galac: Semantic change of basic perception verbs

Argumentum 16 (2020), 125-146

Debreceni Egyetemi Kiadó

DOI: 10.34103/ARGUMENTUM/2020/9

\section{Appendix}

\begin{tabular}{|c|c|c|c|c|c|c|}
\hline & English & German & French & Spanish & Italian & Hungarian \\
\hline Exp. & see & sehen, schauen & voir & ver & vedere & lát \\
\hline Ag. & $\begin{array}{l}\text { look at, } \\
\text { watch }\end{array}$ & $\begin{array}{l}\text { sehen, ansehen, zusehen, } \\
\text { schauen, anschauen, zuschauen, } \\
\text { gucken, blicken, betrachten }\end{array}$ & regarder & mirar & guardare & néz \\
\hline P. & look & aussehen & $\begin{array}{l}\text { (sembler, paraitre, } \\
\text { avoir l'air [...]) }\end{array}$ & $\begin{array}{l}\text { (tener [...] aspecto, } \\
\text { parecer, verse) }\end{array}$ & $\begin{array}{l}\text { (sembrare, avere [...] } \\
\text { aspetto) }\end{array}$ & kinéz (látszik) \\
\hline Exp. & hear & hören & entendre (ouï) & oír (sentir) & sentire (udire) & hall \\
\hline Ag. & listen to & $\begin{array}{l}\text { hören, anhören, zuhören, } \\
\text { lauschen (horchen) }\end{array}$ & écouter & escuchar & ascoltare & hallgat \\
\hline P. & sound & klingen, sich anhören (tönen) & (sonner) & (sonar) & (suonare) & $\begin{array}{l}\text { hangzik, szól ([...] hangja } \\
\text { van, hallatszik) }\end{array}$ \\
\hline Exp. & smell & riechen & sentir & oler (sentir) & sentire odore di $[\ldots]$ & érez \\
\hline Ag. & smell & riechen an & sentir (flairer) & oler & $\begin{array}{l}\text { sentire, odorare, annusare, } \\
\text { fiutare }\end{array}$ & szagol, megszagol \\
\hline P. & smell & riechen & $\begin{array}{l}\text { sentir [...] } \\
\text { (avoir une odeur de [...]) }\end{array}$ & oler a $[\ldots]$ & $\begin{array}{l}\text { sentire di }[\ldots] \text {, odorare, } \\
\text { (avere odore di }[\ldots] \text { ) }\end{array}$ & $\begin{array}{l}\text { ([...] szagú, [...] szaga } \\
\text { van, érződik, szaglik) }\end{array}$ \\
\hline Exp. & taste & schmecken & sentir le goût de qc & $\begin{array}{l}\text { saborear, degustar, } \\
\text { sentir, notar }\end{array}$ & sentire il sapore, gustare & érez \\
\hline Ag. & taste & $\begin{array}{l}\text { probieren, kosten } \\
\text { (schmecken) }\end{array}$ & goûter, déguster & $\begin{array}{l}\text { probar, saborear, } \\
\text { degustar }\end{array}$ & $\begin{array}{l}\text { assaggiare, gustare, } \\
\text { degustare, assaporare }\end{array}$ & kóstol, megkóstol, ízlel \\
\hline P. & taste & schmecken & $\begin{array}{l}\text { (avoir un goût de [...], être); } \\
\text { goûter [Belg., Can. etc.] }\end{array}$ & $\begin{array}{l}\text { saber de }[\ldots] \\
\text { (estar/ser) }\end{array}$ & $\begin{array}{l}\text { sapere di }[\ldots] \text { (avere sapore } \\
\text { di [...], essere, sentire di [...]) }\end{array}$ & $\begin{array}{l}\text { ([...] ízü, [...] íze van, } \\
\text { érződik, ílik) }\end{array}$ \\
\hline Exp. & feel & fühlen & sentir & sentir & sentire & érez \\
\hline Ag. & feel & $\begin{array}{l}\text { tasten, betasten, fühlen, } \\
\text { befühlen, anfühlen }\end{array}$ & toucher, tâter & tocar, palpar & toccare, palpare, tastare & tapint, tapogat, érint \\
\hline P. & feel & sich anfühlen & (être) & (ser/estar) & (essere) & $\begin{array}{l}\text { ([...] tapintású, } \\
{[\ldots] \text { tapintása van, }} \\
{[\ldots] \text { érzete van) }}\end{array}$ \\
\hline
\end{tabular}

